\title{
Relative immunocompetence of the newborn harbour seal, Phoca vitulina
}

\author{
Peter S. Ross ${ }^{\text {a,b }}$, Rik L. de Swart ${ }^{\text {a,b }}$, Ilona K.G. Visser ${ }^{a, b}$, Lies J. Vedder ${ }^{a}$, \\ Willem Murk ${ }^{\mathrm{b}}$, W. Don Bowen ${ }^{\mathrm{c}}$, Albert D.M.E. Osterhaus, ${ }^{*, \mathrm{a}, \mathrm{b}, \mathrm{d}}$ \\ -Seal Rehabilitation and Research Centre, Hoofdstraat 94a, 9968 AG Pieterburen, Netherlands \\ 'Laboratory of Immunobiology, National Institute of Public Health and Environmental Protection, \\ 3720 BA Bilthoven. Netherlands \\ 'Marine Fish Division, Bedford Institute of Oceanography, Dartmouth, N.S. B2Y 4A6, Canada \\ 'Department of Virology, Erasmus University, P.O. Box 1738, 3000 DR Rotterdam. Netherlands
}

(Accepted 27 October 1993)

\begin{abstract}
The immune system of many mammalian species is not fully developed at birth, with newborns obtaining temporary immunological protection from maternal antibodies. Little is known of the immune system of the harbour seal, and developmental aspects of its immune system have not been systematically studied. We collected blood and milk samples from nine free-ranging mother-pup pairs throughout the lactation period on Sable Island, Canada, in an effort to characterise developmental aspects of the immune system of this newborn pinniped. Pup lymphocytes responded stronger to the mitogens concanavalin A, phytohaemagglutinin, and pokeweed mitogen than the lymphocytes of their mothers. In contrast to newborn cats and dogs, newborn seal pups developed high specific antibody responses after immunisation with an inactivated rabies vaccine. Circulating levels of total IgG in newborn pups were low ( $3 \%$ of maternal levels), but increased rapidly after colostrum intake (to $65 \%$ of maternal levels after 15 days). A similar pattern of increase in pup serum was observed for phocine distemper virus specific antibodies which had been detected in the serum and milk of mothers, suggesting that the transfer of colostral antibodies is an important feature of temporary protection for the pup. We speculate that the relative
\end{abstract}

*Corresponding author at: Seal Rehabilitation and Research Centre, Hoofdstraat 94a, 9968 AG Pieterburen, Netherlands. Tel. (31)(0)5952-8285; FAX (31)(0)5952-8389. 
immunocompetence of the harbour seal at birth reflects an adaptation to its relatively short nursing period and limited maternal care.

\section{Abbreviations}

BSA, bovine serum albumin; CDV, canine distemper virus; Con $A$, concanavalin $A$; EDTA, ethylenediaminetetraacetic acid; ELISA, enzyme-linked immunosorbent assay: FCS, foctal calf serum; Ig, immunoglobulin; PBMC, peripheral blood mononuclear cells; PBS, phosphate buffered saline; PDV, phocine distemper virus; PHA, phytohacmagluttinin; PWM, pokeweed mitogen; RFFIT, rapid fluorescent-focus inhibition test; SPF, specific pathogen free; $\mathrm{VN}$, virus neutralisation.

\section{Introduction}

Harbour seals, Phoca vitulina, are found in mid to northern latitudes in the Pacific and the Atlantic Oceans. They spend much of their time at sea, and come ashore predominantly during the breeding season in May to June in North America and June to July in Europe. The newborn harbour seal spends approximately 24 days with its mother, during which time the pup grows rapidly, with a mean mass gain of $800 \mathrm{~g} \mathrm{day}^{-1}$ (Bowen et al., 1992). At birth, the seal pup may be subjected to often severe environmental conditions. Weather conditions and topography, in particular, affect their chances of survival (Baker and Baker, 1988; Steiger et al., 1989; Boness et al., 1992). The influence of infectious diseases on the survival of young pinnipeds is less well documented, but many bacterial and viral infections have been identified among seal pups (Baker and Baker, 1988; Baker, 1989; Visser et al., 1993). How these infections relate to the immunological status of the seals is more difficult to ascertain, as little information exists.

Interest in the immunology of marine mammals increased considerably following the 1988 phocine distemper virus (PDV) epizootic among harbour seals ( $P$. vitulina) and grey seals (Halichoerus grypus) in Europe, and concerns about the possible role of environmental pollutant-induced immunosuppression (Dietz et al., 1989; Osterhaus et al., 1990; De Swart et al., 1994). Additional mass mortalities among Baikal seals (Phoca sibirica) in 1987 (Grachev et al., 1989; Osterhaus et al., 1989), and striped dolphins (Stenella coeruleoalba) in the Mediterranean Sea in 1990-1991 (Van Bressem et al., 1992; for review see Visser et al., 1993), have generated further scientific interest in the state of health of marine mammals, and in factors which may predispose them to disease.

Mammals are generally born with a poor specific immunologic response to pathogens, and rely upon a combination of non-specific defences and temporary protection from passively acquired maternal antibodies for protection against early infections (Banks, 1982). Many studies have identified clear deficiencies in the immune system of mammalian neonates, including low lymphokine production (Winter et al., 1983), poor neutrophil chemotaxis (Schuit and Homisch, 1984 ), poorly developed responses of lymphocytes to mitogens (Gerber and 
Brown, 1974; Holan et al., 1991), and inadequate antibody responses to antigens (Jacoby et al., 1969; Lewis et al., 1973). A suppressive action of T-cells may play a role in the diminished immune response of newborns (Clement et al., 1990). Macrophage function also appears to be impaired, possibly as a result of inhibitory factors present in the serum of the neonate (McKay and Lu, 1991). However, some studies document relatively good responses for some parameters, including mitogen-induced lymphocyte proliferation (Handzel et al., 1980; Winters, 1981 ). The lack of specific memory cells in newborn mammals is, in part, made up for by the transfer of specific antibodies from the mother. This transfer may take place transplacentally, via colostrum, or a combination of both, depending on the type of placentation in different mammalian species. The specificities of these transferred antibodies are a direct reflection of those present in the mother's serum.

In a study of the northern fur seal (Callorhinus ursinus), Cavagnolo and Vedros (1979) found low levels of immunoglobulins G, M, and A (IgG, IgM, IgA, respectively) in pup serum at birth, and steadily rising levels during early life. Carter et al. (1990) found low IgG levels in grey seal pups aged less than 1 week, and slowly rising levels over the first 6 weeks of life. Information on the cellular immune responses of seals is limited, but in a preliminary study, we showed that peripheral blood mononuclear cells (PBMC) from harbour seal pups showed strong proliferative responses to concanavalin A (Con A) compared with lymphocytes of their mothers at mid-lactation (Ross et al., 1993). No information exists as to the ability of young pinnipeds to mount an immunological response to antigens in vivo, or as to the relative importance of maternally derived immunoglobulins to pup serum antibody levels.

The study described here focuses on the development of passively and actively acquired immunocompetence in newborn harbour seals during the lactation period, and the ability of seal pups to mount antibody responses is compared with that of young dogs and cats.

\section{Methods}

\subsection{Sample collection}

Free-ranging harbour seal mothers and their pups were studied during MayJune 1991 on Sable Island, Nova Scotia, Canada $\left(43^{\circ} 55^{\prime} \mathrm{N}, 60^{\circ} 00^{\prime} \mathrm{W}\right)$. Daily monitoring and tagging of all newborn pups on Sable Island enabled us to capture pups which had yet to suckle for the first time, as well as their mothers. To confirm that pups had not yet suckled, a $0.64 \mathrm{~cm}$ diameter KI-100 foal stomach tube (Kalaijan Industries, Long Beach, CA) was inserted into the stomach of the pup, and a $60 \mathrm{cc}$ syringe (Becton Dickinson, Rutherford, $\mathrm{NJ}$ ) used to evacuate any contents. Pups with colostrum present in their stomachs were excluded from the study. Those pups with empty stomachs were marked, weighed and their blood sampled from the extradural vein. Three $10 \mathrm{ml}$ heparinised Vacutainers and one 
$2 \mathrm{ml}$ ethylenediaminetetraacetic acid (EDTA) tube (Becton Dickinson) were filled and inverted gently 15 times. The same series of blood samples was also taken from the mothers. Following blood sampling, mothers were lightly sedated with 10-15 mg of Diazepam (Sabex, Boucherville, Canada), administered intravenously, and given 15-30 IU of Oxytocin (Phoenix Pharmaceutical, St. Joseph, MI) in the gluteal muscle to permit a milk sample to be collected. At each capture, a $30 \mathrm{ml}$ sample of milk was evacuated by suction using a $60 \mathrm{cc}$ syringe with the end removed. Pairs were recaptured for sampling at 2, 5, 10 and 15 days postparturition. Mothers and pups were held for about 10-15 min at each capture and released together. Body weights of harbour seal pups doubled by 15 days of age, from a mean $( \pm S E)$ of $10.9 \pm 0.4 \mathrm{~kg}$ to $21.7 \pm 1.1 \mathrm{~kg}$. Thus, healthy pups with normal weight gain patterns were studied.

Milk was aliquoted in $5 \mathrm{ml}$ samples and stored at $-20^{\circ} \mathrm{C}$ until analysis. Blood samples were kept at room temperature until processing in a field laboratory within $4 \mathrm{~h}$. EDTA samples were used for a total leukocyte count. Erythrocytes were lysed using $50 \mu \mathrm{l}$ whole blood in $1 \mathrm{ml} 2 \%$ acetic acid solution, and leukocytes counted using a haemocytometer (Spotlite, American Hospital Supply Corporation, McGaw Park, IL). One drop of blood was smeared onto a glass microscope slide, air dried, fixed with $95 \%$ methanol and stored at room temperature until stained with May-Grünwald/Giemsa (Hudson and Hay, 1980). Leukocyte subpopulations were classified as band cells, neutrophils, lymphocytes, monocytes, eosinophils, and basophils, and counted.

Peripheral blood mononuclear cells (PBMC) were collected and cryopreserved at two points in lactation from both mothers and pups: at birth and 10 days post-parturition. Heparinised blood was layered on a Histopaque-1077 (Sigma Chemical Company, St. Louis, MO) and centrifuged for $30 \mathrm{~min}$ at $400 \times g$. The PBMC layer was aspirated and cryopreserved as outlined by Ross et al. (1993). Briefly, cells were suspended in RPMI-1640 medium (GIBCO, Life Technologies, Paisley, UK) containing 20\% heat inactivated foetal calf serum (FCS), 10\% dimethylsulphoxide, $100 \mathrm{IU} \mathrm{ml}^{-1}$ penicillin and $100 \mu \mathrm{g} \mathrm{ml}^{-1}$ streptomycin. They were then frozen at a controlled rate in a portable liquid nitrogen container and stored at $-140^{\circ} \mathrm{C}$ or colder until assayed.

\subsection{Lymphocyte stimulation assays}

Cryopreserved PBMC were thawed quickly at $37^{\circ} \mathrm{C}$ and resuspended in $10 \mathrm{ml}$ ice-cold culture medium consisting of RPMI-1640 supplemented with $10 \%$ heat inactivated FCS, penicillin (100 IU ml-1), streptomycin $\left(100 \mu \mathrm{g} \mathrm{ml}^{-1}\right), L$-glutamine $(2 \mathrm{mM})$ and 2-mercaptoethanol $\left(2 \times 10^{-5} \mathrm{M}\right)$. Cells were washed once ( $10 \mathrm{~min}$ at $400 \times \mathrm{g}$ ), resuspended in $10 \mathrm{ml}$ culture medium, and kept at $37^{\circ} \mathrm{C}$ for $4 \mathrm{~h}$. Viable cells were counted on the basis of trypan blue exclusion. PBMC were cultured in 96-well, round-bottomed culture plates $\left(10^{5}\right.$ cells per well; Greiner Labor Technik, Nurtingen, Germany) in culture medium at $37^{\circ} \mathrm{C}$ in a humidified atmosphere of $5 \% \mathrm{CO}_{2}$. Mitogens were added at concentrations found to be optimal in preliminary experiments on cryopreserved cells and in previous stud- 
ies of harbour seal PBMC (De Swart et al., 1993; Ross et al., 1993). These were $2.5 \mu \mathrm{g} \mathrm{ml}^{-1}$ Con A (ICN Biomedicals, Costa Mesa, CA), $20 \mu \mathrm{g} \mathrm{ml}^{-1}$ phytohaemagglutinin (PHA-M; Boehringer, Mannheim, Germany), and $1.0 \mu \mathrm{g} \mathrm{ml}^{-1}$ pokeweed mitogen (PWM; ICN Biomedicals). PBMC were cultured for $96 \mathrm{~h}$ and ${ }^{3} \mathrm{H}$-thymidine was added for the last $18 \mathrm{~h}$. Cells were harvested and cell-associated radioactivity was measured in a Betaplate liquid scintillation counter (LKB, Wallac, Finland).

\subsection{Measurement of total immunoglobulin concentrations}

A protein A (from Staphylococcus aureus, Boehringer) based enzyme-linked immunosorbent assay (ELISA) was used to estimate total IgG levels in the serum and milk of seals. In a variation of the previously described system (Ross et al., 1993), high-binding, flat-bottomed 96-well ELISA plates (Costar, Cambridge, MA) were coated with $1.0 \mu \mathrm{g} \mathrm{ml}^{-1}$ of protein A (Boehringer) in carbonate buffer (pH 9.6) at $37^{\circ} \mathrm{C}$ for $2 \mathrm{~h}$. Plates were washed twice in $0.01 \%$ Tween 20 -water solution (Tween 20; Merck-Schuchardt, München, Germany), and blocked at $37^{\circ} \mathrm{C}$ for $1 \mathrm{~h}$ with ELISA buffer consisting of $1 \%$ bovine serum albumin (BSA) Fraction V (Sigma), $0.1 \%$ Tween 20 (Merck-Schuchardt), $0.1 \%$ Triton (MerckSchuchardt), and $5 \% \mathrm{NaCl}$ in phosphate buffered saline (PBS; $0.001 \mathrm{M}$ ). Twofold serial dilutions of serum samples in ELISA buffer were added to the wells, and plates incubated at $37^{\circ} \mathrm{C}$ for $1 \mathrm{~h}$. Plates were washed twice, and protein $\mathrm{A}$ coupled to horseradish peroxidase (Amersham International, Amersham, UK) in ELISA buffer was added to each well. Plates were incubated at $37^{\circ} \mathrm{C}$ for $1 \mathrm{~h}$, washed twice, and developed as described elsewhere (Bunschoten et al., 1989). Plates were read at $450 \mathrm{~nm}$ using a Titertek Multiskan MCC-340 spectrophotometer.

Seal serum samples were run over a sodium dodecyl sulphate polyacrylamide gel electrophoresis (SDS-PAGE) gel. One millilitre of $\mathrm{NH}_{4} \mathrm{SO}_{4}$ precipitated harbour seal serum (prepared as outlined in Habeeb and Francis, 1976) was buffered with $250 \mu \mathrm{l}$ phosphate buffer $(\mathrm{pH} 8.1,0.5 \mathrm{M}$ ) and applied to a $3.5 \mathrm{ml}$ protein A-Sepharose (CL-48; Pharmacia, Uppsala, Sweden) column as outlined in Ey et al. (1978). The non-binding fraction and citrate ( $\mathrm{pH} 3.0,0.1 \mathrm{M})$ eluted binding fraction were collected separately. These two fractions, plus seal serum and high molecular weight protein standards (BRL), were run in a PhastGel (Pharmacia) homogeneous $12.5 \%$ SDS-PAGE and stained with Coomassie Brilliant Blue.

\subsection{Measurement of naturally occurring, virus-specific antibodies}

Seal serum and milk samples were tested for antibodies against morbilliviruses with a canine distemper virus (CDV) ELISA, using methods described elsewhere (Visser et al., 1989). PDV was used in virus neutralisation (VN) assays as described previously (Visser et al., 1990). Briefly, the VN assays tested the ability of heat inactivated serum sample dilutions to neutralise $30 \mathrm{TCID}_{50}$ of virus cultured in Vero cells. Vero cell culture followed a $1.5 \mathrm{~h}$ co-incubation of $30 \mathrm{TCID}_{50}$ 
PDV with two-fold serial dilutions of serum starting at $1: 20$. VN assays could not be performed on milk samples because of the toxicity of the samples to Vero cells.

\subsection{Immunisation with rabies vaccine}

Four age groups of seal pups on Sable Island were immunised with an inactivated human rabies vaccine (Connaught Laboratories, Toronto, Canada) without adjuvant. Pups independent of the mother-pup study were used in this experiment. Newborn $(n=5), 3$-day-old $(n=6), 6$-day-old $(n=6)$, and 10-day-old $(n=6)$ pups were immunised, and blood was sampled precisely 10 days later. A serum separation tube (Becton Dickinson) was filled with blood taken from the extradural vein. The sample was centrifuged for $20 \mathrm{~min}$ at $500 \times \mathrm{g}$ within $4 \mathrm{~h}$ of sampling, and the serum was aspirated and frozen at $-20^{\circ} \mathrm{C}$ for later assay for rabies virus specific antibodies. In a follow-up experiment, six healthy harbour seals older than 8 months, that were housed at the Seal Rehabilitation and Research Centre, were immunised and sampled following the same protocol as used on Sable Island. These served as a reference group for the immunised pups.

In two parallel experiments, specific pathogen free (SPF) kittens were immunised with the same rabies vaccine and SPF Beagle dog pups were immunised with another rabies vaccine with a similar potency (National Institute of Public Health and Environmental Protection, Bilthoven, Netherlands) without adjuvant in an effort to compare the patterns of humoral responses of seal pups to these better studied species of carnivores. Dog pups and kittens were rabies antibody negative as determined in an ELISA pre-screen. Dog pups were immunised at three different ages: newborn $(n=3), 6$ days $(n=3)$ and 10 days $(n=3)$ postparturition, and a group older than 8 months $(n=4)$. SPF kittens were immu-

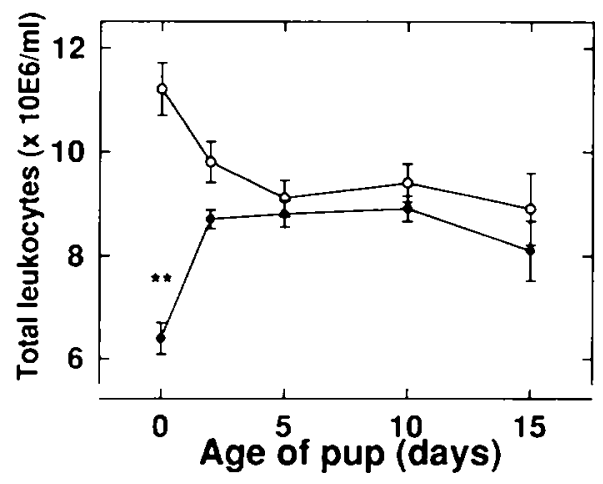

Fig. 1. Mean ( \pm SE) total leukocyte counts in harbour seal pups (solid symbol) and their mothers (open symbols) during the first 15 days of the nursing period (based on a sample size of nine mothers and nine pups). Significant differences between mothers and pups are indicated for time point by * $(P<0.05)$ or ${ }^{* *}(P<0.01)$, as measured by a $t$-test. 
nised at four different ages: newborn $(n=4), 3$ days $(n=5), 6$ days $(n=5)$ and 10 days $(n=5)$ post-parturition. Serum samples were collected 10 days following immunisation, and were frozen until assayed for rabies virus specific antibodies.

\subsection{Measurement of rabies virus specific serum antibodies}

Serum samples of immunised animals were assayed for rabies virus specific antibodies using a rapid fluorescent-focus inhibition test (RFFIT) for the detection of rabies virus neutralising antibodies. The RFFIT was undertaken as described elsewhere (Zalan et al., 1979), using the Pasteur strain of rabies virus, and the results were expressed in international units.

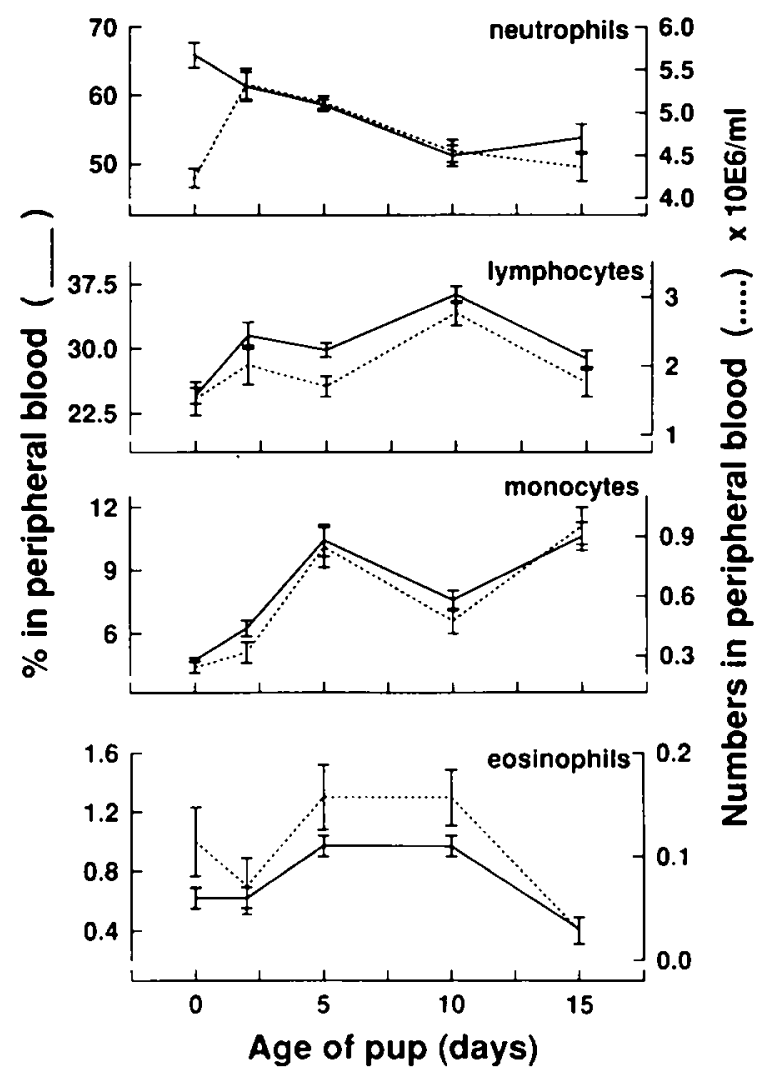

Fig. 2. Differential leukocyte counts of harbour seal pups (mean $\pm S E, n=9$ ) during the first 15 days of the nursing period, expressed as percentages of total cells counted (solid lines), and as concentration in blood (dotted lines). 


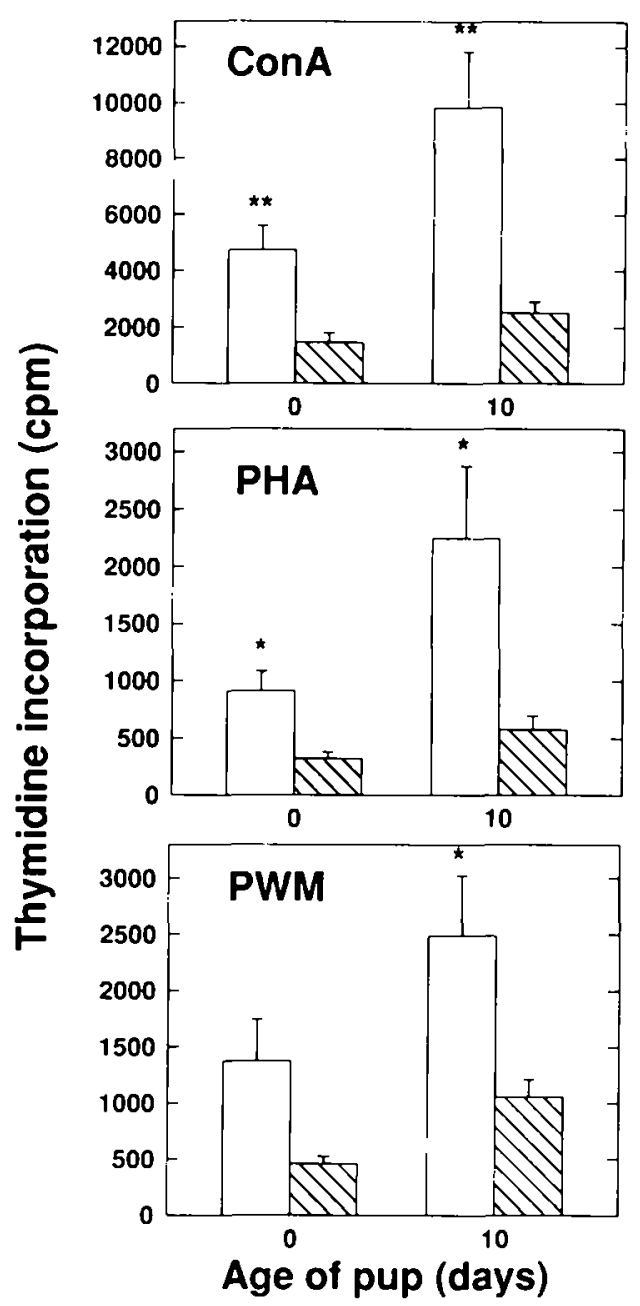

Fig. 3. Mean ( \pm SE) proliferative responses of harbour seal PBMC in vitro from pups (open bars; $n=8$ at Day $0 ; n=5$ at Day 10 ) at two points during the nursing period, and from their mothers (hatched bars; $n=7$ at Day $0 ; n=8$ at Day 10 ). PBMC were stimulated with the plant lectins Con $A$ $\left(2.5 \mu \mathrm{g} \mathrm{ml}^{-1}\right)$, PHA $\left(20 \mu \mathrm{g} \mathrm{ml}^{-1}\right)$, and PWM $\left(1.0 \mu \mathrm{g} \mathrm{ml}^{-1}\right)$ and results are expressed as mean $( \pm \mathrm{SE})$ counts per minute ( $\mathrm{cpm})$ of ${ }^{3} \mathrm{H}$-thymidine incorporation. Significant differences between mothers and pups for time points are indicated by $*(P<0.05)$ or ${ }^{* *}(P<0.01)$, as mcasured by a $t$-test.

\section{Results}

\subsection{Profiles of circulating leukocytes}

Pups were born with significantly lower total leukocyte counts than their mothers (Fig. 1). However, pups acquired similar total leukocyte counts by 2 days of age. Differential counts suggested that the observed rise between birth and 2 days of age reflected an increase in the numbers of lymphocytes and neutrophils, and 


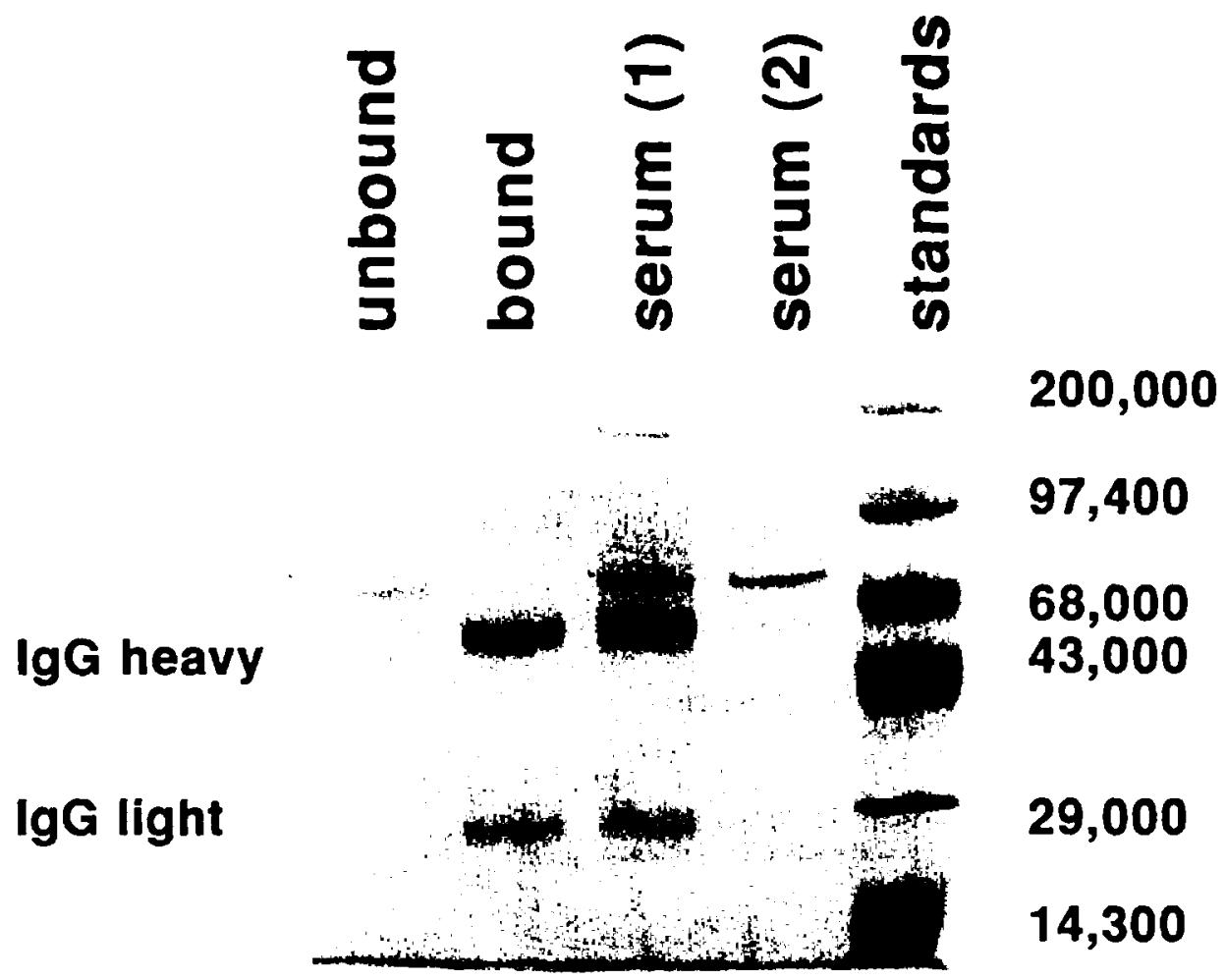

Fig. 4. SDS-PAGE of seal serum, with fractions including protein A bound, protein A unbound, two samples of harbour seal serum, and standards. The heavy and light chain fractions of IgG can be clearly seen in the protein $\mathrm{A}$ bound fraction, but are not visible in the unbound fraction.

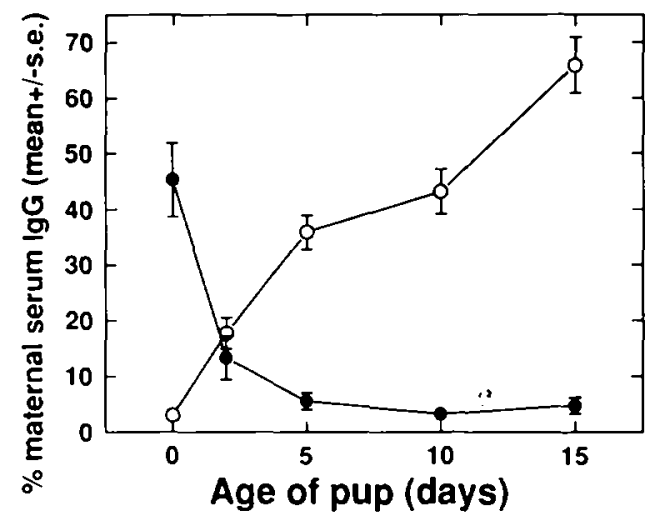

Fig. 5. Mean ( \pm SE) IgG levels in pup serum (open symbols; $n=9$ ) and in their mother's milk (closed symbols; $n=9$ ) from birth to 15 days of age, expressed as a percentage of the mean maternal IgG concentration. IgG was measured by a protein A ELISA. 
to a lesser extent in the numbers of monocytes (Fig. 2). Low numbers of circulating neutrophils, lymphocytes and monocytes contributed to the low total leukocyte counts at birth, with a sudden rise in neutrophils taking place on Day 2 post-parturition. However, the overall increase in lymphocyte and monocyte numbers throughout lactation appeared to be the principal factor in the increased total leukocyte count, as the percentage of neutrophils declined later in the lactation period. Eosinophil counts were low when compared with other cell types, and showed fluctuation through lactation.

\subsection{Lymphocyte proliferation assays}

The functionality of harbour seal lymphocytes was tested by determining their proliferative capacity upon stimulation with three different mitogens. Harbour
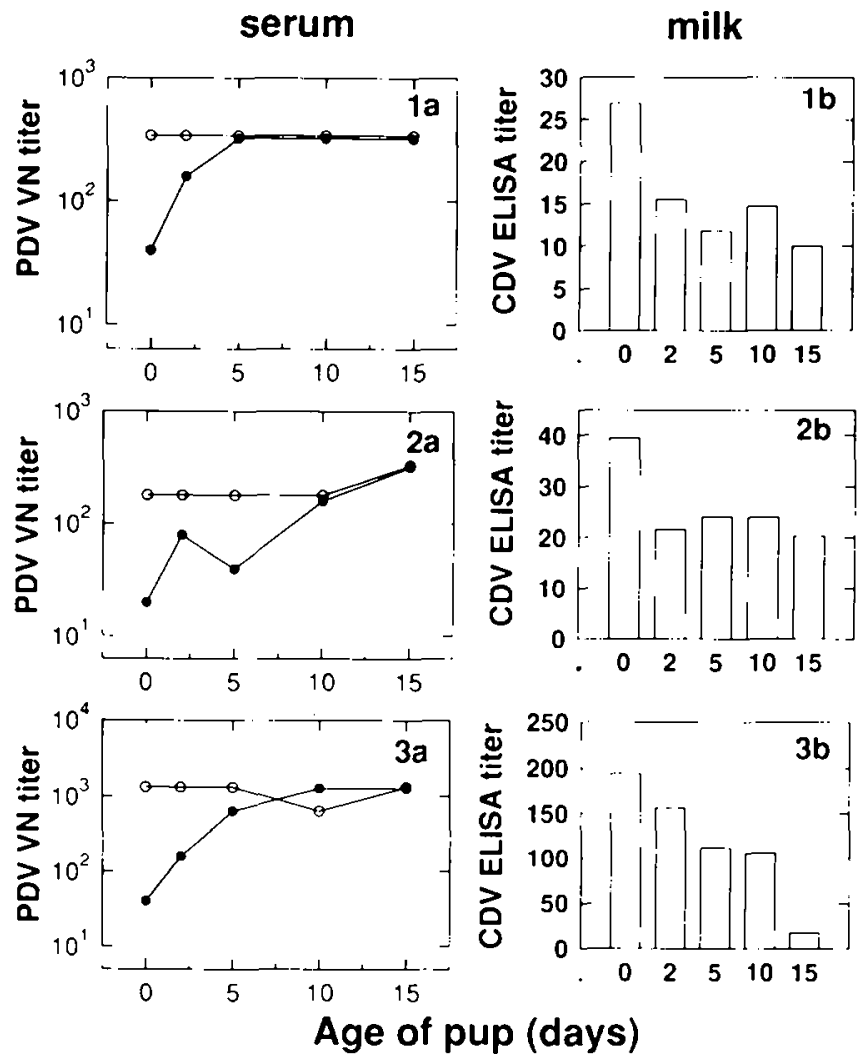

Fig. 6. Virus neutralisation (VN) titres against PDV-1 in three CDV ELISA positive harbour seal mothers (open symbols) and their pups (closed circles) from birth to 15 days of age (mother-pup pairs shown as $1 \mathrm{a}, 2 \mathrm{a}, 3 \mathrm{a})$, and CDV ELISA titres for milk ( $1 \mathrm{~b}, 2 \mathrm{~b}, 3 \mathrm{~b})$. 
seal pup PBMC showed two to four times higher proliferative responses to Con A, PHA and PWM than those of their mothers at birth and at 10 days of age (Fig. 3). Responses of pup PBMC tended to be higher at 10 days of age than at birth, although these differences were not significant.

\subsection{Transfer of maternal protein $A$ binding immunoglobulins to pups}

The SDS-PAGE of seal serum enabled us to assess the efficacy of protein A in binding seal IgG heavy and light chains. Protein A was shown to bind the majority of IgG in harbour seal serum, with the non-binding fraction having little detectable light or heavy chains of IgG (Fig. 4). Pups were born with about $3 \%$ of maternal serum protein $\mathrm{A}$ binding $\mathrm{IgG}$ concentrations, with this figure rising to about $65 \%$ at 15 days of age (Fig. 5 ). Colostrum contained about $45 \%$ of protein A binding IgG levels compared with those found in the maternal serum, whereas milk later in lactation had relatively low concentrations, declining to about $5 \%$.

\subsection{Transfer of specific antibodies to pups}

To investigate in more detail the contribution of maternal antibodies to the serum antibodies in the pups, we screened mother's serum for specific antibodies acquired through a previous infection, and subsequently screened their pups in order to differentiate between antibody transfer via colostrum and milk and antibody produced by the pup. Three of the nine mothers studied had CDV reactive serum antibodies as demonstrated by the CDV ELISA without showing evidence of infection at the time of sampling (results not shown). Pups of these mothers had very low CDV ELISA titres at birth (mean of $2 \%$ of maternal titres), but by 10-15 days of age, the same pups had titres approaching those of their mothers (mean of $63 \%$ of maternal titres). Colostrum had a high concentration of specific antibodies, with levels at $96 \%$ of those in maternal serum, whereas milk at Day 15 post-parturition contained $32 \%$. Virus neutralisation data substantiated the protein A based CDV ELISA data, with pups being born with low levels of PDVneutralising antibodies (mean of $9 \%$ of maternal serum values), and attaining maternal levels towards 10 days of age (Fig. 6 ).

\subsection{Antibody response to rabies immunisation}

Seal pups responded strongly to rabies immunisation within the 10 day incubation time, as measured by the RFFIT (Fig. 7). Seal pups in the 3-day-old age group were best able to mount a response, having a titre which was significantly higher than that of the older seals tested. The pattern of antibody responses clearly contrasts with those observed in the dogs and the cats. Dog pups of the same age categories (no 3-day-old group was tested) did not mount strong rabies virus specific responses compared with adult dogs (Fig. 7). Like dog pups, young kittens displayed a relatively poor response to rabies immunisation at birth relative to seal pups, with a slight increase at 10 days of age (Fig. 7). 


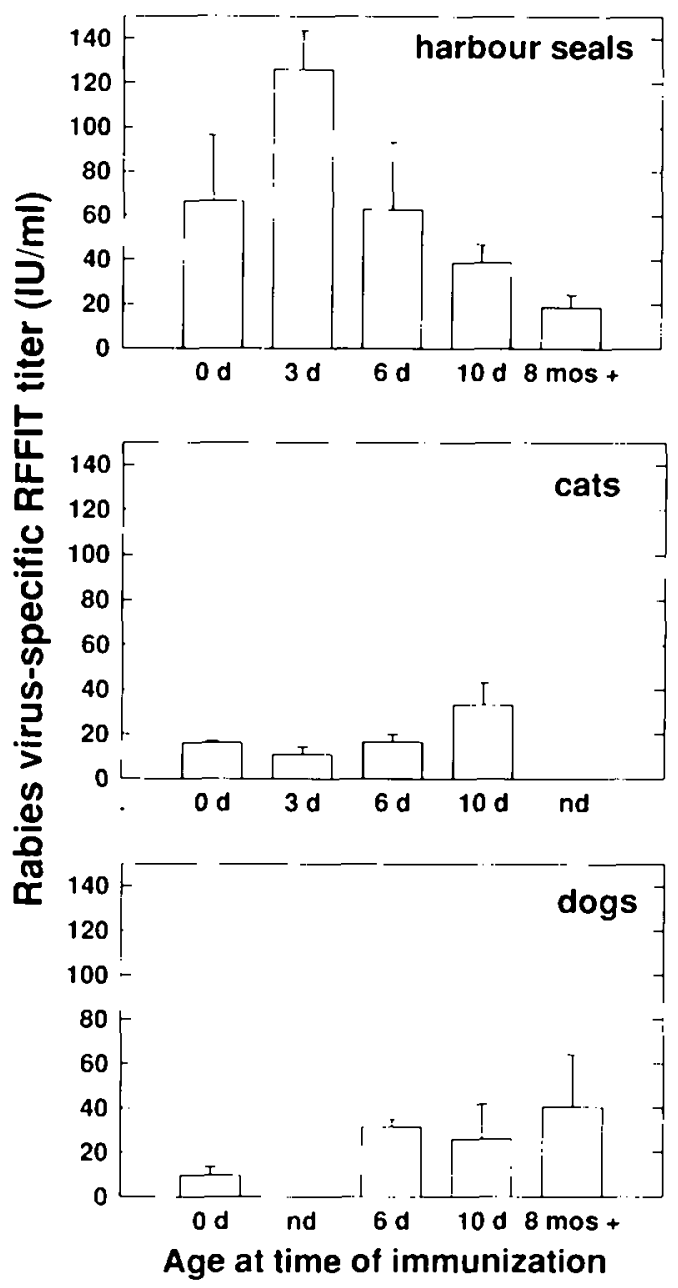

Fig. 7. Antibody responses of harbour seals ( $n=5,6,6,6$ for each age group, respectively). kittens $(n=4$. $5,5,5$ for each age group, respectively), and Beagle pups $(n=3$ for each age group and $n=4$ for the group 8 months or over) to inactivated human rabies vaccine 10 days following immunisation. Values are expressed in international units (IU) (mean \pm SE) as determined by a rapid fluorescence focus inhibition test (RFFIT). nd, not done. Seal pups aged 3 days had a significantly higher antibody response than those aged 8 months or more $(P<0.001)$.

\section{Discussion}

The results of our in vitro and in vivo tests suggest that the newborn harbour seal is born with a functionally competent immune system, although serum antibodies of the $\mathrm{IgG}$ class are virtually absent. High levels of total protein A binding IgG and PDV-specific antibodies in milk at parturition suggest that colostrum is 
an important source of $\mathrm{IgG}$ for newborn harbour seals. The low levels of total $\mathrm{IgG}$ in the serum of seal pups at birth, followed by their rapid increase during lactation provide further support for this view. Protein A has been used extensively in immunologic studies, and has been shown to bind to the $\mathrm{Fc}$ region of $\mathrm{IgG}$ in many mammals (Goding, 1978; Langone, 1982). It is also routinely used for the measurement of both specific (Visser et al., 1989) and total IgG levels (Ross et al., 1993 ) in the harbour seal. Our SDS-PAGE results support the use of protein A as an immunologic reagent in the harbour seal, as the majority of IgG in seal serum bound to protein A beads. Although all mammals rely on maternal immunoglobulins for a certain degree of temporary protection after birth, the relative importance of transplacental versus colostral transfer varies according to the type of placentation. Transplacental transfer of IgG in the harbour seal seems to be minimal, consistent with their endotheliochorial placentation (Dierauf et al., 1986) which is largely impermeable to IgG (Tizard, 1987). Dogs and cats are other examples of mammals with endotheliochorial placentation, and are born with 5$10 \%$ of maternal serum IgG concentrations (Tizard, 1987). However, on the basis of total serum levels of IgG in harbour seal pups, we could not initially exclude that the rapid rise in IgG levels shortly after birth was due to endogenously produced immunoglobulins. We therefore measured antigen-specific antibodies in milk and pup serum where the mother had been identified as antibody-positive as a consequence of a previous infection and their pups showed no signs of infection. The patterns of specific antibody titres in colostrum/milk and in pup serum, as measured by both a protein A based ELISA and a biologically based VN assay, strongly suggest that maternal immunoglobulins are responsible for a large part of the observed increases in pup serum. As the pattern of these maternally derived specific antibodies was similar to our observed pattern of total IgG increase in the pups, it seems reasonable to conclude that the serum IgG in 15-day-old pups originates predominantly from the absorption of colostral/milk antibodies and that there is limited endogenous production of IgG during that time.

The increase in IgG levels observed in our study of harbour seal pups during lactation is more dramatic than those reported for other pinniped species. Cavagnolo and Vedros (1979) found that IgG increased to $26 \%$ of maternal levels in the northern fur seal by 35 days of age. This may be related to species differences in maternal lactation strategy, as the northern fur seal pup nurses less frequently, and over a longer period of 3 months (Gentry and Holt, 1986). Serum levels at birth were comparable to those in our study, being $5 \%$ of maternal values. Carter et al. (1990) also found a slow rate of increase in IgG levels in grey seal pups, attaining only $15 \%$ of maternal values by $4-5$ weeks of age. Sanders and Ortiz (1992) found IgG levels to rise from $9 \%$ at 2 days of age to $39 \%$ of maternal values at weaning in the northern elephant seal, Mirounga angustirostris.

The protection of young mammals from virus infections by specific maternal antibodies has been demonstrated in several species (Paul, 1983; Milner and Marshall, 1984; Sweet et al., 1987; Jakeman et al., 1989; Mbawuike et al., 1990). The three harbour seal newborns that obtained PDV-specific antibodies via colostrum/milk in our study have essentially been passively immunised against infection by morbilliviruses. We previously showed that the virus which elicited these antibodies in Canadian waters was closely related, if not identical, to PDV, 
the virus responsible for the 1988 European epizootic among harbour seals (Ross et al., 1992). Although little is known of patterns in seals, in other mammals the half-life of maternal $\mathrm{IgG}$ in newborn serum averages approximately 12-18 days. This implies that protection against specific pathogens can last for several months, depending on the original titre in the milk (Winters, 1981; Paul, 1984).

The strong proliferative responses of pup PBMC to the three mitogens reflect the capacity of both $\mathrm{T}$ and $\mathrm{B}$ lymphocytes of the newborn seal to respond to polyclonal antigens. Con A and PHA elicit specific T lymphocyte responses in mammals, while PWM stimulates both B and T lymphocytes (Möller, 1972; Greaves et al., 1974). The specificity of these mitogens in stimulating harbour seal $\mathrm{T}$ and B lymphocytes has recently been confirmed by De Swart et al. (1993). Responses of newborn lymphocytes in other mammalian species vary, but are not completely consistent with the patterns observed in our study seals. We must assume that the responses of mothers' PBMC to mitogens are representative of the 'normal' activity of adult seal PBMC, but cannot entirely rule out that the physiological and/or hormonal stress of the breeding period affected their immune responses (Ross et al., 1993). In dogs, lymphocyte responses to PHA and PWM are significantly lower at birth than in adults (Krakowka and Koestner, 1976). Gerber and Brown (1974) found canine lymphocytes to be non-responsive to PHA from birth to 4 weeks of age. Holan et al. (1991) found that newborn mice lymphocytes were unresponsive to Con $\mathrm{A}$, and cited immature $\mathrm{T}$ lymphocytes and neonatal suppressor cell activity. Hammerberg et al. (1989) found that newborn pigs had relatively low PWM-induced lymphocyte proliferation, and that other aspects of humoral immunity were also impaired. Studies of human newborns, however, showed that their lymphocytes respond well to mitogens (Campbell et al., 1974; Alford et al., 1976; Hayward, 1981).

The ability of the newborn harbour seal pup to respond to a primary antigen, tested here by the antibody response after immunisation with inactivated rabies vaccine, was strong, whether in comparison with the response found in older seals (over 8 months of age), or pups and kittens of any age. While dog bitches had been identified as rabies-antibody negative in an ELISA pre-screen, subsequent RFFIT identified very low levels of rabies virus neutralising antibodies in their serum. These may have been the result of a vaccination of the bitches more than 5 years previously, and may have resulted in very low levels of VN antibodies in the serum of the dog pups $\left(0.2 \mathrm{IU} \mathrm{ml}^{-1}\right.$ or less $)$ prior to the immunisation experiment. Although we cannot entirely exclude a negative influence of these maternal antibodies on the responses of dog pups, the very low levels observed before immunisation, coupled with the similar response pattern in kittens, suggest that the dog pups responded normally to immunisation.

The apparent immunocompetence of the harbour seal neonate relative to other mammals may reflect a combination of its large birth mass relative to mothers, its long gestation period (estimated at 9-10 months by Boulva and McLaren (1979)), its short period of suckling (mean weaning age is 24 days), and its precocial nature at birth. This is in line with the observations of Banks (1982), who noted that mammals with short gestation periods (i.e. less than 30 days) 
had poor immune responses compared with those with longer gestation periods. However, gestation length alone cannot fully explain immunological differences among newborn mammals. Humans, for example, have a gestation length similar to harbour seals, yet are born with some noted immunological deficiencies (see e.g. Andersson et al., 1981; Winter et al., 1983). The seal pup must independently cope with its environment within a very short time of birth, and an active cellular immune system, coupled with temporary protection from maternally derived antibodies may be a vital component of their precocial nature.

\section{Conclusion}

The newborn harbour seal is born with low levels of circulating immunoglobulins. The high colostral concentrations of total and specific immunoglobulins, and subsequent increase in pup serum concentrations through the nursing period suggest that obtaining colostrum early in lactation is an important aspect of temporary immunological defence. Newborn harbour seals appear to have a relatively competent immune system which is primed for antigenic challenge. This was evidenced by in vivo antibody responses to immunisation with an inactivated rabies vaccine and by strong lymphocyte proliferation in response to in vitro stimulation with mitogens (Con A, PHA and PWM). The relative immunocompetence of the harbour seal pup appears to be in contrast with a number of observations of other mammalian species. We suggest that this reflects an evolutionary adaptation to its short nursing period and limited maternal care.

\section{Acknowledgements}

The authors would like to thank Dr. Hans Kreeftenberg and Connaught Laboratories (Toronto, Ont., Canada) for the gift of inactivated rabies vaccine; Sara Iverson and Daryl Boness for field assistance; G. Forbes of the Atmospheric Environment Service for ongoing logistic support on Sable Island; Geert van Amerongen, Jolande Boes, Heinz W.J. Broeders, Jan Groen and Marco van de Bildt for technical and logistical support with experiments; Conny Kruyssen for help in preparing the manuscript; Fisheries and Oceans Canada and the Natural Sciences and Engineering Research Council of Canada for operating grants to WDB. Research was also supported in part by a Natural Sciences and Engineering Research Council of Canada award to PSR.

\section{References}

Alford, R.H., Cartwright, B.B. and Sell, S.H.W., 1976. Ontogeny of human cell-mediated immunity: age-related variation of in vitro infantile lymphocyte transformation. Infect. Immun., 13:11701175. 
Andersson, U., Bird, A.G., Britton, S. and Palacios, R., 1981. Humoral and cellular immunity in humans studied at the cell level from birth to two years of age. Immunol. Rev.. 57: 5-38.

Baker, J.R., 1989. Natural causes of death in non-suckling grey seals (Halichoertus grypus). Vet. Rec.. 125: 500-503.

Baker, J.R. and Baker, R., 1988. Effects of environment on grey seal (Halichoerus grypus)m pup mortality. Studies on the Isle of May. J. Zool. London, 216: S29-537.

Banks, K.L., 1982. Host defense in the newborn animal. JAVMA, 181: 1053-1056.

Boness, D.J., Bowen, D., Iverson, S.J. and Oftedal, O.T., 1992. Influence of storms and maternal size on mother-pup separations and fostering in the harbor seal, Phoca vitulina. Can. J. Zool., 70: $1640-1644$.

Boulva, J. and McLaren, I.A., 1979. Biology of the harbor seal, Phoca vitulina in eastern Canada. Bull. No. 200, Fisheries Research Board of Canada, 24 pp.

Bowen, W.D., Oftedal, O.T. and Boness, D.J., 1992. Mass and energy transfer during lactation in a small phocid, the harbor seal (Phoca vitulina). Physiol. Zool., 65: 844-866.

Bunschoten, H., Gore, M., Claassen, I.J.Th.M., UytdeHaag, F.G.C.M., Dietzscold, B., Winner, W.H. and Osterhaus, A.D.M.E., 1989. Characterization of a new virus-neutralization epitope that denotes a sequential determinant on the rabies virus glycoprotcin. J. Gen. Virol., 70: 291-298.

Campbell, A.C., Waller, C., Wood, J., Aynsley-Green, A. and Yu, V., 1974. Lymphocyte subpopulations in the blood of newborn infants. Clin. Exp. Immunol., 18: 469-482.

Carter, S.D., Hughes, D.E. and Baker, J.R., 1990. Characterization and measurement of immunoglobulins in the grey seal (Halichoerus grypus). J. Comp. Pathol., 102: 13-23.

Cavagnolo, R.Z. and Vedros, N.A., 1979. The immunology of marine mammals. Dev. Comp. Immunol., 3: 245-257.

Clement, L.T., Vink, P.E. and Bradley, G.E., 1990. Novel immunoregulatory functions of phenotypically distinct subpopulations of CD4 + cells in the human neonate. J. Immunol., 145: 102-108.

De Swart, R.L., Kluten, R.M.G., Huizing, C.J., Vedder, L.J., Reijnders, P.J.H., Visser, I.K.G., UytdeHaag, F.G.C.M. and Osterhaus, A.D.M.E., 1993. Mitogen and antigen induced B cell and T cell responses of peripheral blood mononuclear cells from the harbour seal (Phoca vitulina). Vet. Immunol. Immunopathol., 37: 217-230.

De Swan, R.L., Ross, P.S., Vedder, L.J., Timmerman, H.H., Heisterkamp, S.H., van Loveren, H., Vos, J.G., Reijnders, P.J.H., and Osterhaus, A.D.M.E., 1994. Impairment of immune function in harbour seals (Phoca vitulina) feeding on fish from polluted waters. Ambio, in press.

Dicrauf, L.A., Dougherty, S.A. and Lowenstine, L.J., 1986. Survival versus nonsurvival determinants for nconatal harbor seals. JAVMA, 189: 1024-1028.

Dietz, R., Heide-Jørgensen, M.-D. and Härkönen, T., 1989. Mass deaths of harbor seals (Phoca vitulina) in Europe. Ambio, 18: 258-264.

Ey, P.L., Prowse, S.J. and Jenkin, C.R., 1978. Isolation of pure IgG I, IgG2a, and IgG2b immunoglobulins from mouse serum using protein $A$ sepharose. Immunochemistry, 15: 429-436.

Gentry, R.L. and Holt, J.R., 1986. Attendance behavior of northern fur seals. In: Fur Seals: Maternal Strategies on Land and at Sea. Princeton University Press, Princeton, NJ, pp. 41-60.

Gerber, J.D. and Brown, A.L., 1974. Effect of development and aging on the response of canine lymphocytes to phytohemagglutinin. Infect. Immun., 10: 695-699.

Goding, J.W., 1978. The use of staphylococcal protcin A as an immunological reagent. J. Immunol. Methods, 20: 241-253.

Grachev, M.A., Kumarev, V.P., Mamev, L.V., Zorin, V.L., Baranova, L.V., Denikina, N.N., Belikov, S.I., Petrov, E.A., Kolesnik, V.S., Kolesnik, R.S., Dorofeev, V.M., Beim, A.M., Kudelin, V.N., Nagieva, F.G. and Sidorov, V.N., 1989. Distemper virus in Baikal seals. Nature, 338: 209-210.

Greaves, M., Janossy, G. and Doenhoff, M., 1974. Selective triggering of human T and B lymphocytes in vitro by polyclonal mitogens. J. Exp. Med., 140:1-18.

Habeeb, A.F.S.A. and Francis, R.D., 1976. Preparation of human immunoglobulin by ammonium sulfate precipitation. Vox Sang., 31: 423-434.

Hammerberg, C., Schurig, G.G. and Ochs, D.L., 1989. Immunodeficiency in young pigs. Am. J. Vet. Res., 50: 868-874. 
Handzel, Z.T., Levin, S., Dolphin, Z., Schlesinger, M., Hahn, T., Altman, Y., Schechter, B., Shneyour, A. and Trainin, N., 1980. Immune competence of newborn lymphocytes. Pediatrics, 65: 491-496.

Hayward, A.R., 1981. Development of lymphocyte responses and interactions in the human fetus and newborn. Immunol. Rev., 57: 39-59.

Holan, V., Lipoldova, M. and Zajicova, A., 1991. Immunological nonreactivity of newborn mice: Immaturity of $T$ cells and selective action of neonatal suppressor cells. Cell. Immunol., 137: 216223.

Hudson, L. and Hay, F.C., 1980. Practical Immunology, 2nd edn. Blackwell Scientific, Oxford, 359 pp.

Jacoby, R.O., Dennis, R.A. and Griesemer, R.A., 1969. Development of immunity in fetal dogs: humoral responses. Am. J. Vet. Res., 30: 1503-1510.

Jakeman, K.J., Smith, H. and Sweet, C., 1989. Mechanism of immunity to influenza: maternal and passive neonatal protection following immunization of adult ferrets with a live Vaccinia-Influenza virus haemagglutinin recombinant but not with recombinants containing other Influenza virus proteins. J. Gen. Virol., 70: 1523-1531.

Krakowka, S. and Koestner, A., 1976. Age-related susceptibility to infection with canine distemper virus in gnotobiotic dogs. J. Infect. Dis., 134: 629-632.

Langone, J.J., 1982. Protein A of Staphylococcus aureus and related immunologic receptors produced by streptococci and pneumococci. Adv. Immunol., 32: 157-252.

Lewis, R.M., Smith, C.A. and Garfield, L., 1973. Kinetics of antibody synthesis to particulate and soluble antigen in newborn pups and adult dogs. Am. J. Vet. Res., 34: 235-240.

Mbawuike, I.N., Six, H.R., Cate, T.R. and Couch, R.B., 1990. Vaccination with inactivated Influenza $A$ virus during pregnancy protects neonatal mice against lethal challenge by Influenza $A$ viruses representing three subtypes. J. Virol., 64: 1370-1374.

McKay, D.B. and Lu, C.Y., 1991. Listeriolysin as a virulence factor in Listeria monocytogenes infection of neonatal mice and murine decidual tissue. Infect. Immun., 59: 4286-4289.

Milner, A.R. and Marshall, I.D., 1984. The role of colostrum and milk in protection of the neonatal mouse against peripheral infection with Ross River virus. Arch. Virol., 82: 101-104.

Möller, G. (Editor), 1972. Lymphocyte activation by mitogens. Transplant. Rev., 11: 1-267.

Osterhaus, A.D.M.E., Groen, J., UytdeHaag, F.G.C.M., Visser, I.K.G., van de Bildt, M.W.G., Bergman, A. and Klinghorn, B., 1989. Distemper virus in baikal seals. Nature, 338: 209-210.

Osterhaus, A.D.M.E., Groen, J., Spijkers, H.E.M., Broeders, H.W.J., UytdeHaag, F.G.C.M., de Vries, P., Teppema, J.S., Visser, I.K.G., van de Bildt, M.W.G., and Vedder, E.J., 1990. Mass mortality in seals caused by a newly discovered morbillivirus. Vet. Microbiol., 23: 343-350.

Paul, P.S., 1984. Persistence of passively acquired antibodies to hemagglutinating encephalomyelitis virus in swine. Am. J. Vet. Res., 45: 932-934.

Ross, P.S., Visser, I.K.G., Broeders, H.W.J., van de Bildt, M.W.G., Bowen, W.D., and Osterhaus, A.D.M.E., 1992. Antibodies to phocine distemper virus in Canadian seals. Vet. Rec., 130: 514516.

Ross, P.S., Pohajdak, B., Bowen, W.D. and Addison, R.F., 1993. Immune function in free-ranging harbor seal (Phoca vitulina) mothers and their pups during the nursing period. J. Wildlife Dis., 29: $21-29$.

Sanders, J.L. and Ortiz, C.L., 1992. Immunoglobulin levels in milk and serum of northern elephant seal females and their pups. Foetal and Neonatal Pathobiology No. 344. (Abstr.)

Schuit, K.E. and Homisch, L., 1984. Inefficient in vivo neutrophil migration in neonatal rats. J. Leukocyte Biol., 35: 583-586.

Steiger, G.H., Calambokidis, J., Cubbage, J.C., Skilling, D.E., Smith, A.W. and Gribble, D.H., 1989. Mortality of harbor seal pups at different sites in the inland waters of Washington. J. Wildlife Dis., 25: 319-328.

Sweet, C., Jakeman, K.J. and Smith, H., 1987. Role of milk-derived IgG in passive maternal protection of neonatal ferrets against Influenza. J. Gen. Virol., 68: 2681-2686.

Tizard, I., 1987. Veterinary Immunology: An Introduction. W.B. Saunders, Philadelphia, PA, 401 pp.

Van Bressem, M.F., Visser, I.K.G., van de Bildt, M.W.G., Teppema, J.S., Raga, J.A. and Osterhaus, 
A.D.M.E., 1992. Morbillivirus infection in Mediterranean striped dolphins (Stenella coerts. leoalha). Vet. Rec., 129: 471-472.

Visser, I.K.G., van de Bildt, M.W.G., Brugge, H.N., Reijnders, P.J.H., Vedder, E.J., Kuiper, J., de Vrics, P., Walvoor, H.C., UytdeHaag, F.G.C.M. and Osterhaus, A.D.M.E., 1989. Vaccination of harbour seals (Phoca vitulina) against phocid distemper with two different inactivated canine distemper (CDV) vaccines. Vaccine, 7: 521-526.

Visser, I.K.G., Kumarev, V.P., Orvell, C., de Vries, P., Broeders, H.W.J., van de Bildı, M.W.G., Groen. J., Teppema, J.S., Burger, M.S., UytdeHaag, F.G.C.M. and Osterhaus, A.D.M.E., 1990. Comparison of two morbilliviruses isolated from seals during outbreaks of distemper in North West Europe and Siberia. Arch. Virol., 111: 149-164.

Visser, I.K.G., van Bressem, M.F., Barrett, T. and Osterhaus, A.D.M.E., 1993. Morbillivirus infections in aquatic mammals. Vet. Res., 24: 169-178.

Winter, H.S., Gard, S.E., Fischer, T.J., Bryson, Y.J. and Stiehm, E.R., 1983. Deficient lymphokine production of newborn lymphocytes. Pediatr. Res., 17: 573 -578.

Winters, W.D., 1981. Time-dependent decreases of maternal canine vinus antibodies in newborn pups. Vet. Rec., 108: 295-299.

Zalan, E., Wilson, C. and Pukitis, D., 1979. A microtest for the quantitation of rabies virus neutralizing antibodies. J. Biol. Stand., 7: 213-220. 